\title{
E-commerce as a tool to boost the development of Cuban agribusiness companies
}

\author{
El comercio electrónico como herramienta para impulsar el desarrollo de las \\ empresas agroindustriales cubanas
}

\author{
R. Perdigón-Llanes iD
}

\begin{abstract}
E-commerce represents a driving force for the economic development of enterprises and businesses. Ecommerce is widely used in developed countries, however, it is considered an alternative commercialization channel in developing countries. The development of electronic commerce in Cuba is incipient, mainly in institutions of the agribusiness sector that base their businesses on traditional models. This situation affects the commercial and economic development of these organizations and difficult the supply of food to the Cuban agricultural market. In this research, a strategy was developed to implement e-commerce in a medium-sized enterprise in the Cuban agro-industrial sector. Historical-logical method, in-depth interview, surveys, participant observation, theoretical triangulation and modeling were used as scientific methods. The strategy is aimed to improving the commercial management of the company and promoting its commercial and economic development. This paper contributes to increase the efficiency of Cuban agribusiness companies and the food market in this country through the use of e-commerce.
\end{abstract}

Index Terms - Agribusiness; commercialization; digital strategy; e-commerce; small and medium-sized enterprises.

Resumen- El comercio electrónico representa un elemento impulsor del desarrollo económico de empresas y negocios. El comercio electrónico posee una amplia utilización en países desarrollados, sin embargo, es considerado un canal de comercialización alternativo en países en vías de desarrollo. El desarrollo del comercio electrónico en Cuba es incipiente, principalmente en instituciones del sector agroindustrial que basan sus negocios en modelos tradicionales. Esta situación afecta el desarrollo comercial y económico de estas organizaciones y dificulta el abastecimiento de alimentos al mercado agropecuario cubano. En esta investigación se elaboró una estrategia para implementar el comercio electrónico en una mediana empresa del

This manuscript was sent on August 15, 2019 and accepted on March 13, 2020. This work was supporting by the Trading Company "Frutas Selectas" of Pinar del Rio, under project investigation "Estrategia de comercio electrónico para mejorar la gestión comercial de la Empresa Comercializadora Frutas Selectas de Pinar del Río".

R. Perdigón-Llanes, is IT Manager in the Trading Company "Frutas Selectas" of Pinar del Río, Cuba. (e-mail: rperdigon90@gmail.com; rudibel@frutaspr.co.cu) sector agroindustrial cubano. Se utilizaron como métodos científicos el histórico-lógico, la entrevista a profundidad, la encuesta, la observación participante, la triangulación teórica y la modelación. La estrategia está orientada a mejorar la gestión comercial de la entidad y a impulsar su desarrollo comercial y económico. Esta investigación contribuye a elevar la eficiencia de las empresas agroindustriales cubanas y del mercado de alimentos en el país mediante el empleo del comercio electrónico.

Palabras claves - Agronegocios; comercialización; estrategia digital; comercio electrónico; pequeñas y medianas empresas

\section{INTRODUCTION}

A GRIBUSINESS is the field where economics, business and agriculture come together [1]. Agribusiness is the businesses of agricultural production that include the harvesting, distribution, processing, marketing and commercialization of agricultural products to end customers [1], [2]. These businesses represent a determining element in the growth of Gross Domestic Product (GDP) in Latin American countries [2].

Agricultural products are mainly commercialized under two systems that are categorized as centralized and decentralized and differ in the form of concentration of power [3]. Ecommerce is one of the channels for agricultural products commercialization that has a wide application in developed western economies, such as in United States and Europe [4]. During 2015 in the United States 14\% of the agricultural enterprises with Internet connection made electronic commercial transactions [5]. However, e-commerce is still considered an alternative distribution channel in the agribusiness sector in underdeveloped countries [4]. This is due to the limited application of digital technologies in the distribution chains of primary agricultural products and in basic processes in this sector [6].

E-commerce is defined as the use of the Internet and digital technologies to buy, sell and trade data, goods or services [7]. This type of business generates several economics profits and its use by the world's companies grows rapidly [8]. Records from the Global Web Index site show that in $201875 \%$ of Internet users used this form of business and according to [9], 
in 2015 the global e-commerce market exceeded $\$ 25$ billion in revenue. In addition, e-commerce contributed in 2016 to increase in $2.92 \%$ the global GDP according to data from the ECommerceWiki site. E-commerce enables organizations to realize substantial cost savings, increase revenues, provide faster deliveries, reduce administration costs and improve customer service [10].

At present, there is a wide literature related to the development, benefits and implementation of electronic commerce, mainly in nations of the Asian continent [8], [11], [12]. The adoption of e-commerce in the agribusiness sector is a topic of interest to the international scientific community [11]. However, in Cuba the development of electronic commerce is still incipient [13], mainly in companies of the agribusiness sector. These companies base their businesses on traditional models mainly in face-to-face relations with clients. This situation affects the commercial and economic development of Cuban agribusiness companies and negatively affects the availability of food in the Cuban agricultural market.

Enterprises represent an important element of economic activities in nations [14]. In Cuba, the enterprises constitute the fundamental actor of the Cuban economic model. Cuban companies involved in the production and commercialization of agricultural products contribute to the supply of food to different sectors of society and to guaranteeing the country's food security. The commercialization to the tourist system is a fundamental destination of agricultural production in Cuba. The tourist businesses are one of the main activities for the development of the Cuban economy [15]. Increasing the efficiency of the agribusiness companies that supply food to the tourist businesses will contribute to develop the Cuban tourist sector and its economy.

This research proposes a strategy to develop e-commerce as a new business model in a medium-sized enterprise in the Cuban agribusiness sector. The objective of the strategy is to modify the traditional business model developed by this firm in order to contribute to solving the deficiencies that affect its commercial and economic development and increase the quality of its services.

\section{Methodology}

In this research the real case of the Trading Company "Frutas Selectas" in the Cuban province of Pinar del Río was studied. The business of this company is to produce and commercialize fresh and high quality agricultural products to the tourist sector in this province. The scientific methods used in this research were historical-logical, in-depth interview, survey, participant observation, theoretical triangulation and modeling. These methods were used to diagnose the state of the company's commercial management, to know the evolution of e-commerce businesses and to elaborate the digital strategy proposed. The Google Scholar database was used as a search engine for information.

\section{CHARACTERISTICS OF AGRICULTURAL MARKET IN PINAR DEL RIO}

The Cuban agricultural market is a space for the purchase, sale and distribution of agricultural products to different sectors of the Cuban society [16]. Increase the food production is a policy of the Cuban government, however the system of commercialization of these inputs must be improved to achieve greater efficiency in their production [17]. The need to satisfy the demand for food and to guarantee the food security of the Cuban population makes the process of commercialization of agricultural products a relevant element [18].

The agricultural market in Cuba has unique characteristics that differentiates it from its similar in the world and affects its functioning [16]. The lack in the use of digital technologies is one of the factors that affect the functioning of the Cuban agricultural market [16]. According to [17] some challenges to be faced by Cuba's agricultural marketing system are: reducing external dependence of food, increasing import substitution, encouraging exports, increasing agricultural production and commercialization in line with the growing development of tourism and its food's demands.

In addition to above difficulties, there are other elements that affect the agricultural market in the province of Pinar del Río, some are the following [18]:

- The province is in the high-frequency zone of meteorological events.

- High index of losses in crops that implies shortage of the market.

- Difficulties with transportation, packaging and packing.

- Inflexibility of purchase prices.

- Incipient or no marketing approach.

- Violations of technical quality standards in cultivation, sowing and harvesting, resulting in customer displeasure and production losses.

- Non-conformities of the productive forms in the process of economic contracting.

The above elements turn the agricultural market of Pinar del Rio into a challenging and competitive environment, where the private sector, different forms of agricultural production and many companies dedicated to the commercialization of agricultural products coexist. These institutions contribute to the supply of food to various social sectors in Pinar del Rio, including the tourism sector.

\section{DiAgNosis OF THE COMMERCIAL MANAGEMENT OF THE TRADING COMPANY “FRUTAS SELECTAS"}

Commercial management plays a significant role in business systems with a fundamental impact on national economies [18]. Commercial management is the activity related with the study and exchange relations of the organization with the market, the placement in it and at the disposal at the end customer of the products and services provided by the company in exchange for a financial value [19]. Commercial management forms part of the different 
blocks that integrate the business models of organizations and evolves jointly with them [20].

The commercial management of the Trading Company "Frutas Selectas" is made up of the following processes: purchase management, benefit of agricultural products, sales management, logistics and insurance, and customer support service. In the Fig. 1 the relationship between the processes that make up the commercial management of the company is showed. Satisfying client needs is the fundamental institution's objective.

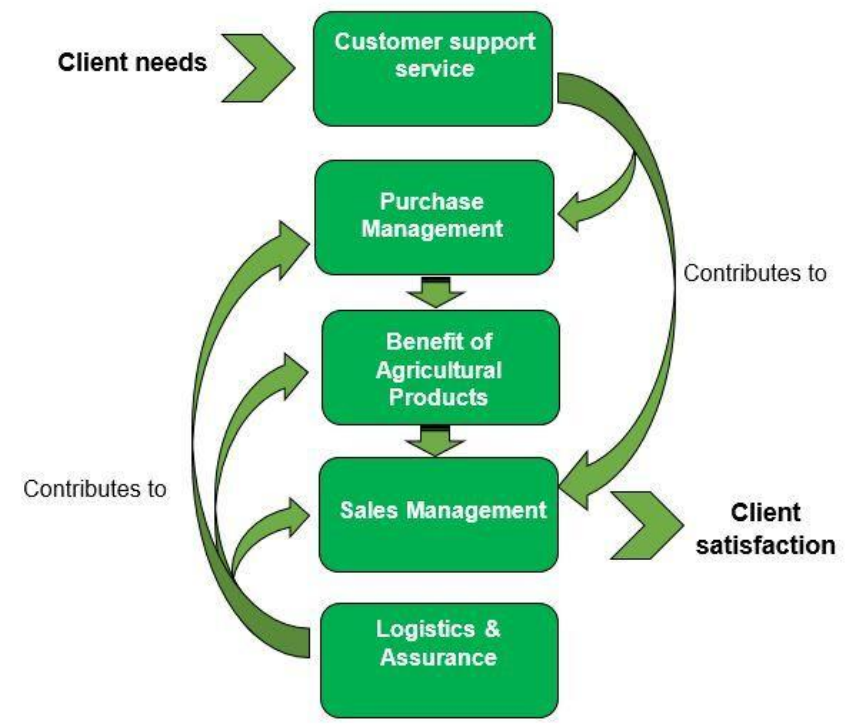

Fig. 1. Commercial Management Process of the Trading Company "Frutas Selectas".

In Fig.2 the way in which agricultural products are commercialized by the Trading Company "Frutas Selectas" of Pinar del Río and the magnitudes in which these goods are distributed to different clients is described. The productive forms that compose the productive chain of the company are the Credit and Services Cooperatives, Basic Units of Cooperative Production, Agricultural Production Cooperatives and independent farmers in Pinar del Rio.

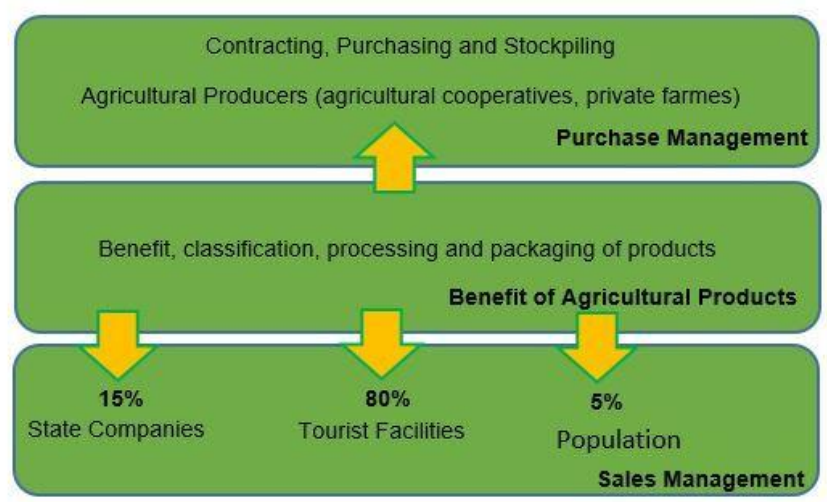

Fig. 2. Commercialization and distribution of agricultural products by the Trading Company "Frutas Selectas".

Sales management is realized after the profit and processing of the products that are collected through purchasing management. During the profit process, value is added to the agricultural products. In correspondence with the social objective of the company, the greater volume of the goods of the institution is directed commercialized to the tourist facilities, although the company also offers its services to other companies of the state and the population too. Cubanacán, Islazul, Habaguanex, Gran Caribe, Gaviota, Campismo, the Palmares's extrahotelera chain, the Cuban Civil Aeronáutica, Cubacatering S.A. and Palco Complex are the main Cuban tourist companies served by the Trading Company "Frutas Selectas" of Pinar del Rio.

A diagnosis to know the state of the commercial management in the Trading Company "Frutas Selectas" of Pinar del Rio was made. In this diagnosis in-depth interview, survey and the participant observation was used as scientific methods for the elaboration of the measurement instruments. The following results were achieved:

- Shortcomings in ensuring a stable supply of products. The procedures established in the institution to ensure the availability of products out of harvest season are insufficient. This reduces the supply of food that are highly demanded by customers in the domestic market, decreases their satisfaction with the services of the company, causes non-compliance with company's purchasing plans and causes economic losses for the institution.

- Insufficiencies in the attention and satisfaction of the client needs. The means used by the company to attend customer needs are inefficient. This causes deficiencies in the company's sales management and decreases customer satisfaction.

- Inefficient integration of ICTs in the commercial management of the organization. The company does not efficiently integrate ICT into its business management processes. This lack reduce the efficiency in the execution of the company's operations and slows down its commercial development.

- Limited automation of the business model of the company. The company develops a traditional business model that fails to take advantage of the potential offered by digital technologies for marketing and business. This constraint affects the execution of the company's business processes and hinders their development.

- Lack of efficient marketing techniques. The absence of a marketing strategy that uses digital technologies efficiently and allows the dissemination of products and services offered by the company causes the loss of potential customers.

The results obtained make it possible to identify that the low development level of the commercial management in the Trading Company "Frutas Selectas" of Pinar del Rio, its insufficient integration with digital technologies and the lack of automation of its business model. These deficiencies hinder 
the commercial and economic development of this company and affect the quality of the services it provides to its clients. This situation negatively affects the supply of food to tourism in the territory. The above elements show the need to modify the commercial management of this company, for this purpose the author propose the application of a strategy that efficiently integrates ICT into its business model.

\section{RESULTS AND DISCUSSION}

The development of digital technologies transformed the evolution of business models because it changed sales and supply channels, created new ways of interacting with customers and changed the market positioning of companies [21], [22]. A business model describes how a business is conducted to generate profits and create value [23]. In Fig. 3 the author show the components of a digital business model in accordance with [23]. The application of these components may be partial or total, depending on the business sector or type of industry in which the business is carried out [23].

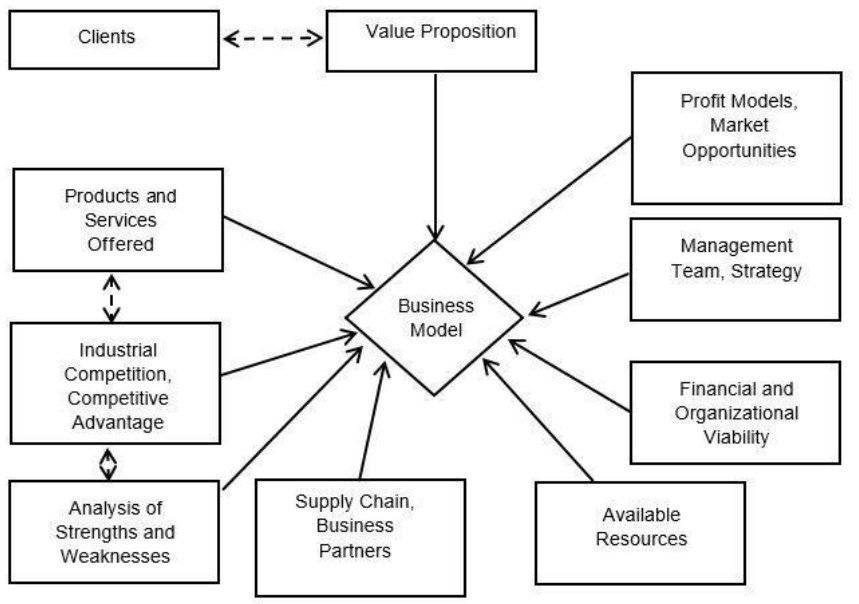

Fig. 3. Components of a digital business model [23].

Describing customers, analyzing how their orders will be met and the organization's value proposition are some important aspects that [23] highlights in his research. He also proposes to identify the competition and its market shares and the strategies of the organization to ensure its competitive advantage in market.

Business models relate to business process management and business strategies [24]. According to [25] a strategy encompasses an organized plan, a pattern, or a global position over time that includes competition. This author [25] considers that there are 2 types of strategies: the private strategies and the strategies of business alliance.

A digital strategy is a means to set goals and action programs to address digital initiatives, measure their progress, and rethink them as needed [26], [27]. Digital strategies represent a response to external opportunities and threats and the transformation of products, processes, organizational aspects and business models through the use of new technologies, to achieve the company's competitive advantage through the provision of online services [21], [26]. Characteristics associated with digital strategies include [26]:
- Focus on operational process efficiency and improve customer experience and/or business model transformation

- They range from unique digital solutions to the most holistic strategies.

- Allows companies to maintain their competitive position.

- They are a facilitator of corporate, business and/or functional strategies.

The proposed strategy is based on the components of a digital business model identified by [23]. To develop this strategy a group of legal, technological, commercial and economic foundations was considered in accordance with the Cuban laws relating with commercialization, use of digital technologies and business improvement. The strategy developed aims to improve the commercial management of Trading Company "Frutas Selectas" through the implementation of e-commerce as its new business model.

According to the types of strategies proposed by [25] the strategy proposed in this research is private and combines the e-commerce models B2B (business-to-business), O2O (onlineoffline), social e-commerce (commerce through social networks) and m-commerce (commerce through mobile devices). This strategy uses digital marketing techniques to attract new business partners and potential customers, contemplates current trends in the development of ecommerce and proposes the use of social networks to achieve a better approach of the company to the customer needs. Figure 4 shows the key components of the strategy.

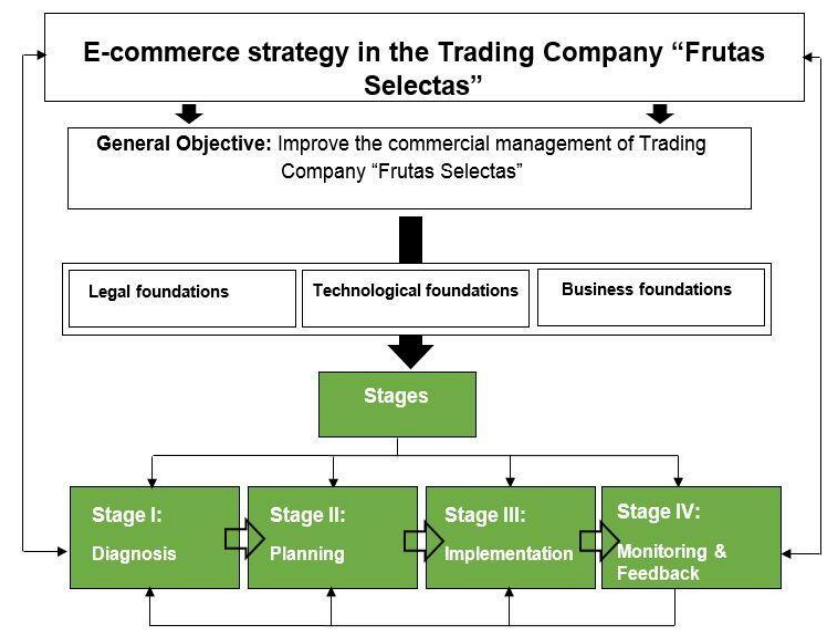

Fig. 4. E-commerce strategy.

The strategy consists of 4 stages that have specific actions in correspondence with the specific objectives of each one and with the proposed general objective. These stages complement each other and cannot be conceived independently of each other. The actions that make up the stages of the strategy contribute to solving the deficiencies identified during the diagnosis of the commercial management of Trading Company "Frutas Selectas" of Pinar del Río. The stages of the strategy are described below:

Stage I: Diagnosis.

Objective: Identify the particularities of the organization's 
value offerings by studying the market, customers and their needs.

At this stage, an analysis is made of the market in which the entity operates, about the characteristics of company's offerings, the products marketed by the institution and the about its businesses process. This stage contributes to identifying the weaknesses of the institution's business model. The following actions are proposed:

- Analyze the commercial and financial performance of the entity to determine the key business processes to be enhance.

- Determine the characteristics of the products to be marketed, their added value and the elements that differentiate them from their peers in the market. It is recommended the use of SWOT matrix (strengths, weaknesses, opportunities and threats).

- Identify and quantify potential customers in the market.

- Establish a correct correspondence between product quality and its price.

- Facilitate different mechanisms to access to products and strengthen their supply chain.

- Establish different marketing channels for different customers.

Stage II: Planning.

Objective: Conceive the strategy and develop IT tools for its implementation.

The execution of this task requires in-depth analysis of competition, study of customer specificities, study of current trends in digital business and an efficient use of ICTs and social media. At this stage, some actions are proposed through the use of ICTs, which contribute to increasing the marketing of the business and the attraction of new clients and commercial partners. These are the actions proposed:

- Analyze the competition.

- Identify similar businesses and analyze the fundamental elements of their proposals.

- Secure the legal permits, technological and administrative resources, materials and personnel necessary to implement e-commerce as a new form of business in the organization.

- Develop software applications that meet design trends, adjustable to mobile devices, easy to use and focused on meeting customer needs. The author proposes to develop an e-commerce website according to the characteristics of the company's business that allows proper interaction with customers and ensures security in commercial transactions.

- Develop a simple, agile and secure sales process that uses different payment mechanisms. A reliable and secure payment gateway must be used to conduct electronic financial transactions. The authors propose the use of the Cuban electronic gateway named PasaRed.

- Create profiles in social networks that make it possible to interact with clients and increase the attraction of new customers and commercial partners.

- Use personalized digital marketing techniques with adequate and truthful contents through different computational techniques to ensure a fast and effective sales management. The author of this research propose to implement content marketing techniques according to the characteristic of the products to be commercialized and enhance the positioning of the business on the web through techniques such as search engine optimization (SEO).

Stage III: Implementation

Objective: Implement the strategy conceived in the business of the Trading Company "Frutas Selectas" of Pinar del Río.

At this stage, the entity's traditional business model is modified. It is proposed as a fundamental action of this stage the following:

- Implement the elements defined in the previous stages in correspondence with the legal, technological, commercial and business foundations assumed.

Stage IV: Monitoring and feedback.

Objective: Correct the identified deficiencies and insufficiencies during the operation of the new business model.

This stage allows redirecting the objectives and scope of the company's business in real time, to avoid market losses, increase competitiveness, and achieve customer's loyalty. In order to achieve this objective, the author proposes the next actions:

- Evaluate the performance of the strategy by measuring company's economic and commercial performance: purchase and sales levels, market increase, company's operating expenses and client's satisfaction.

- Continuously update and follow the business profile on social networks.

- Analyze customer behavior on the business website.

- Create a space on the company's e-commerce website that allows customers to insert their reviews and rate the service.

- Establish an effective communication channel between the company's website administrators and its administration board to execute corrective actions in time.

- Re-elaborate and adjust the strategy according to the results obtained during this stage.

The proposed strategy strengthens the use of digital technologies in the commercial management processes in the Trading Company "Frutas Selectas" of Pinar del Río. The strategy is aimed to improving the efficiency and competitiveness of this company. The active participation of customers in the company's value offerings through social media makes it possible to improve the attention to their needs and raise their levels of satisfaction. 


\section{CONCLUSION}

There are several deficiencies in the Cuban agricultural commercialization system that affect the performance of the Cuban agricultural market, cause food shortages and negatively influence the development of the Cuban agribusiness companies. The diagnosis of the commercial management in the Trading Company "Frutas Selectas" of Pinar del Río showed its insufficient integration with digital technologies and the existence of deficiencies that hinder the commercial and economic development of this company.

A strategy was developed to implement e-commerce as a new business model in the Trading Company "Frutas Selectas" of Pinar del Río in order to improve its commercial management and increase its economic development. The proposed strategy is aimed to increasing the availability of agricultural products in the Cuban market and satisfying the food needs of the tourist sector.

This article contributes to enriching the literature related to the development of agribusiness companies in Cuba and to promoting the use of digital business in the Cuban market in accordance with the Cuban digitalization policy. Future research can be oriented to assess the impact of the proposed strategy through the subsequent analysis of the state of commercial management of Trading Company "Frutas Selectas" of Pinar del Río through a pre-experiment.

\section{REFERENCES}

[1] S. L. Bairwa; A. Kalia; L. K. Meena; K. Lakra; S. Kushwaha. "Agribusiness Management Education: A Review on Employment Opportunities", International Journal of Scientific and Research Publications, vol. 4, no. 2, pp. 1- 4, 2014.

[2] D. E. Sepúlveda; D. Sepúlveda; F. Pérez; E. Figueroa. "Modelo para la adopción del comercio electrónico en el sector agroindustrial mexicano", Análisis Económico, vol. 31, no. 76, pp. 47-73, 2016.

[3] F. J. Arias; S. Rendón. "Modelos descentralizados de comercialización agropecuaria como estrategia para la inclusión social en Colombia: el caso Exofruit SAS", Scientia Agropecuaria, vol. 6, no. 3, pp. 201-209, 2015. DOI: 10.17268/sci.agropecu.2015.03.06

[4] K. Nikolaou; F. Anastasiadis; E. Tsakiridou; K. Mattas. "ExploringValuing Alternative Distribution Channels: A Systematic Literature Review of the Agrifood Sector", in Sustainable Agriculture and Food Security, Springer, 2018, pp. 63-83. DOI: 10.1007/978-3-319-771229

[5] C. Carpio; K. Lange. "Trends in e-commerce for the food marketing system", CAB Reviews: Perspectives in Agriculture, Veterinary Science, Nutrition and Natural Resources, vol. 10, no. 23, pp. 1-8, 2015. DOI: 10.1079/PAVSNNR201510023

[6] D. López; J. González. "TIC, REDES SOCIALES Y LA CADENA DE VALOR PARA LA COMERCIALIZACIÓN DEL CAFÉ", Scientia et Technica, vol. 17, no. 51, pp. 138-144, 2012.

[7] F. E. Bravo-Peña. "EVALUACIÓN DEL "COMERCIO ELECTRÓNICO" COMO CANAL DE COMERCIALIZACIÓN PARA PRODUCTOS DE LA AGRICULTURA FAMILIAR CAMPESINA", tesis de maestría, Universidad de Chile, 2018.

[8] R. Perdigón; H. Viltres; I. R. Madrigal. "Estrategias de comercio electrónico y marketing digital para pequeñas y medianas empresas", Revista Cubana de Ciencias Informáticas, vol. 12, no. 3, pp. 192208, 2018.

[9] T. Fredriksson. "E-Commerce Measurement", in United Nations Conference on Trade and Development, Suzhou, China, 2017.

[10] D. Libu; M. Bahari; N. Iahad; W. Ismail. "Systematic literature review of e-commerce implementation studies", Journal of
Theoretical and Applied Information Technology, vol. 89, no. 2, pp. 422-438, 2016.

[11] Y. Zeng; F. Jia; L. Wan, y H. Guo. "E-commerce in agri-food sector: a systematic literature review", International Food and Agribusiness Management Review, vol. 20, no. 4, pp. 439-459, 2017. DOI: 10.22434/IFAMR2016.0156

[12] J. Sánchez; F. Juárez. "La adopción del comercio electrónico en las Pymes: una revisión de la literatura exploratoria", NOVUM, no.7, pp. 78-94, 2017.

[13] G. Estrada, L. Ferriol, y Y. Álvarez. "Una panorámica de la evolución del comercio electrónico en Cuba", in VIII Congreso Internacional de Tecnologías y Contenidos Multimedia, La Habana, Cuba, 2018.

[14] Z. Qin, Y. Chang, S. Li, F. Li. "E-Commerce Strategy in Enterprises" In E-Commerce Strategy, Berlin, Germany, Ed Springer, 2014. DOI: 10.1007/978-3-642-39414-0_4

[15] M. A. Figueras; Y. Pérez. "Competitividad del destino turístico Cuba: impacto económico", Economía y Desarrollo, vol. 153, no. (Supl. 1), pp. 178-189, 2015.

[16] A. García; R. González. "Mercados agropecuarios en Cuba: evolución, análisis y mejora", Economía y Desarrollo, vol. 156, no. 1, pp. 200-218, 2016.

[17] C. Arias-Salazar. "LA COMERCIALIZACIÓN DE PRODUCTOS AGRÍCOLAS. RETOS Y PERSPECTIVAS", Revista Granmense de Desarrollo Local, vol. 2, no. 3, pp. 136-147, 2018.

[18] A. Fernández; Y. Contreras. "Procedimiento para el perfeccionamiento del Sistema de Comercialización en las Cooperativas de Producción Agropecuaria de la provincia Pinar del Río", Revista de Cooperativismo y Desarrollo, vol. 4, no. 1, pp. 1-11, 2016.

[19] J. E. Ponce. "La gestión comercial y su influencia en el crecimiento de las pymes hoteleras de Manabí", Revista ECA Sinergia, vol. 8, no. 2, pp. 54-68, 2017. DOI: 10.33936/eca_sinergia.v8i2.865

[20] H. Barth; P. O. Ulvenblad; P. Ulvenblad. "Towards a Conceptual Framework of Sustainable Business Model Innovation in the AgriFood Sector: A Systematic Literature Review", Sustainability, vol. 9, no. 9, pp. 1620-1634, 2017. DOI: 10.3390/su9091620

[21] C. Matt, T. Hess, A. Benlian. "Digital Transformation Strategies", Business \& Information Systems Engineering, vol. 57, no. 5, pp. 339343, 2015. DOI: $10.1007 / \mathrm{s} 12599-015-0401-5$

[22] D. A. Cardona; A. Montenegro; H. G. Hernández. "Creación de empresa como pilar para el desarrollo social e integral de la región caribe en Colombia: apuntes críticos", SABER, CIENCIA Y Libertad, vol. 12 , no. 1 , pp. $130-139$, 2017. DOI: 10.18041/23823240/saber.2017v12n1.698

[23] E. Turban, D. King, J.K. Lee, T. P. Liang, D.C. Turban. "Overview of Electronic Commerce", in Electronic Commerce, ed. Springer, Texas, USA, 2015. DOI: 10.1007/978-3-319-10091-3_1, 2015

[24] B. W. Wirtz; A. Pistoia; S. Ullrich; V. Göttel. "Business Models: Origin, Development and Future Research Perspectives", Long Range Planning, vol. 49, no. 1, pp. 36-54, 2016. DOI: 10.1016/j.lrp.2015.04.001

[25] M. Goyanes. "Estrategias y modelos de negocio: aclaración de conceptos y terminología de la prensa en Internet", Estudios sobre el Mensaje Periodístico, vol. 19, no. 1, pp. 419-431, 2013. DOI: 10.5209/rev_ESMP.2013.v19.n1.42530

[26] M. D'Cruz; G. Timbrell; J. Watson. "Strategy in a Digital World", in Australasian Conference on Information Systems, South Australia, 2015, pp. 13.

[27] J. W. Ross; I. M. Sebastian; C. M. Beath. "How to Develop a Great Digital Strategy", MIT SLOAN MANAGEMENT REVIEW, vol. 58, no. 2, pp. 6-10, 2017. 


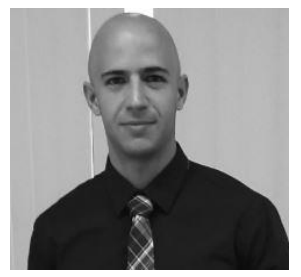

Rudibel Perdigón Llanes received his degree in informatics sciences from Informatics Sciences University, La Havana, Cuba in 2014 and the Master degree in the same university in 2019. He has worked as IT Manager since 2014. His research interests include LINUX systems, e-commerce, emarketing, ITCs and social development.

ORCID: http://orcid.org/0000-0001-7288-6224 